\title{
Rapid semi-quantitative point of care diagnostic test for post vaccination antibody monitoring
}

Maria E. Moeller ${ }^{1}$, Frederik N. Engsig ${ }^{1}$, Melanie Bade ${ }^{2}$, Jeppe Fock ${ }^{2}$, Pearlyn Pah ${ }^{2}$, Anna Louise Soerensen $^{1}$, Didi Bang ${ }^{3}$, Marco Donolato ${ }^{2}$, Thomas Benfield ${ }^{1,4}$

\author{
Affiliations: \\ ${ }^{1}$ Department of Infectious Diseases, Amager Hvidovre Hospital, Hvidovre, Kettegaard Allé 30, \\ 2650 Hvidovre, Denmark \\ ${ }^{2}$ BluSense Diagnostics ApS, Symbion Bioscience Park, Fruebjergvej 3, 2100 Copenhagen, \\ Denmark \\ ${ }^{3}$ Department of Clinical Microbiology, Copenhagen University Hospital, Amager and Hvidovre, \\ Kettegaard Allé 30,2650 Hvidovre, Copenhagen, Denmark \\ ${ }^{4}$ Institute of Clinical Medicine, University of Copenhagen, Copenhagen, Denmark
}

\section{Corresponding author:}

\section{Running head:}

A novel serological semi-quantitative point-of-care diagnostic test for COVID-19; post vaccination

monitoring.

\section{Disclaimers:}

\section{Key words:}

SARS-CoV-2, immuno-magnetic agglutination assay, vaccination, rapid IgG-IgM-IgA combined test, point-of-care, $\mathrm{S}$ protein trimer

\section{No. of tables:}

No. of figures:

Word count:

\section{Abstract:}

\section{Author contributions:}

Conceptualization: MEM, MD, FNE, MB and TB; Formal Analysis: MEM, FNE, JF, MB and MD; Funding acquisition: TB and MD; Investigation: MEM, FNE, DB, MB, JF, PP and MD; Methodology: MD, JF and DB; Supervision: TB and FNE; Visualization: JF; Writing - original draft: MB, JF, MD and MEM; Writing - review \& editing: All. 


\section{ABSTRACT}

Introduction: Point-of-care (POC) quantification of the antibody responses against the SARS-CoV-2 Spike protein can enable decentralized monitoring of immune responses after infection or vaccination. We evaluated a novel POC microfluidic cartridge-based device (ViroTrack Sero COVID-19 Total Ab) for quantitative detection of total antibodies against SARS-CoV-2 Spike trimeric spike protein and compared to standard laboratory chemiluminescence (CLIA) based tests.

Methods: Capillary- and venous blood samples were collected from 101 individuals employed at Copenhagen University Hospital, Denmark. Antibody responses were measured on capillary-, venous whole blood, plasma and diluted plasma samples directly on the POC instrument. POC results were available within seven minutes on the microfluidic cartridge reader. Plasma samples were analysed on the DiaSorin LIAISON ${ }^{\circledast}$ XL CLIA Analyzer using LIAISON ${ }^{\circledast}$ SARS-CoV-2 IgM, LIAISON ${ }^{\circledast}$ SARS-CoV-2 S1/S2 IgG and LIAISON ${ }^{\circledast}$ SARS-CoV-2 TrimericS IgG assays. The data from the CLIA platform was used as a reference.

Results: The Spearman rank's correlation coefficient between ViroTrack Sero COVID-19 Total Ab and LIAISON ${ }^{\circledast}$ SARS-CoV-2 S1/S2 IgG and LIAISON ${ }^{\circledR}$ SARS-CoV-2 TrimericS IgG assays is found to be 0.86 and 0.90 respectively. ViroTrack Sero COVID-19 Total Ab furthermore showed high correlation $(>0.86)$ among the different sample matrixes. The agreement for determination of samples $>200 \mathrm{BAU} / \mathrm{mL}$ on POC and CLIA methods is estimated to be around $90 \%$.

Conclusion: ViroTrack Sero Covid Total Ab is a very rapid and simple-to-use POC test with high sensitivity and high correlation of the numerical results expressed in $\mathrm{BAU} / \mathrm{mL}$ when compared to a commercial CLIA assay.

\section{Key words:}

SARS-CoV-2, immuno-magnetic agglutination assay, total antibodies, spike trimer, vaccination monitoring 


\section{INTRODUCTION}

During coronavirus disease 2019 (COVID-19) pandemic, Severe acute respiratory syndrome coronavirus 2 (SARS-CoV-2) serological testing has been shown to play an important role not only as diagnostic support tool, but also in understanding antibody responses mounted upon SARS-CoV-2 infection and vaccination [1-3].

The spike (S) glycoprotein of SARS-CoV-2 forms surface-exposed homotrimers that mediate viral entry into host cells. Spiked glycoprotein is therefore the main target of SARS-CoV-2-specific neutralizing antibodies upon infection, and the focus of therapeutic and vaccine designs [4-6]. The correlates of protection are based on the specific level of SARS-CoV-2-specific neutralizing antibodies, acquired through vaccination or natural infection, that substantially reduces the risk of (re)infection $[7,8]$.

Antibodies against the $S$ protein are capable of neutralizing the virus and the $S$ protein is therefore the primary antigen target of most of the current SARS-CoV-2 vaccines [9,10]. In clinical trials, antibody production and cellular $\mathrm{T}$ cell responses have been measured for these candidate vaccines [11-15]. It has been shown that a large proportion of the individuals undergoing seroconversion of immunoglobulin $G$ (IgG) antibody responses against the viral S protein generate detectable neutralizing antibody responses [7], and that $S$ protein binding assays correlate significantly with neutralization of wild-type SARS-CoV-2 virus [16-22]. Among the different subunits, the $S$ protein in its trimeric form, when used in serology assays has a high sensitivity[23] and specificity[22].

Quantification of antibody responses and conversion rates of vaccinated populations can provide useful information not only to estimate the variety of vaccine responses and duration of protection, but also to enhance vaccine immunogenicity, dosage optimization, amount and time intervals $[9,24]$. Therefore, it is inevitable that SARS-CoV-2 S-based assays play an essential role in vaccine efficacy monitoring. 
medRxiv preprint doi: https://doi.org/10.1101/2021.09.17.21263729; this version posted September 22, 2021. The copyright holder for this preprint (which was not certified by peer review) is the author/funder, who has granted medRxiv a license to display the preprint in perpetuity.

It is made available under a CC-BY-NC-ND 4.0 International license .

Several quantitative IgG or total antibody tests based on enzyme-linked immunoassay (ELISA) or chemiluminescence based instruments (CLIA) have been commercialized and their performances evaluated in depth [25-27]. However, none of these methods are applicable for antibody quantification in decentralized settings. Standardization of the First WHO International Standard for anti-SARS-CoV-2 immunoglobulin (human) (NIBSC code 20/136) has been introduced to allow for comparability between assay results. The International Standard is based on pooled human plasma from convalescent patients, which is lyophilized in ampules, with an assigned unit of 250 international units (IU) per ampule for neutralizing activity. For binding assays, a unit of 1000 binding antibody units (BAU) per $\mathrm{ml}$ can be used to assist the comparison of assays detecting the same class of immunoglobulins with the same specificity [28].

The threshold of protection for anti-SARS-CoV-2 S protein antibodies acquired by vaccination is an object of research in the recent phase of the pandemic. Initial studies show that antibody levels associated with immunity against symptomatic COVID-19 infection measures about 150-200 BAU /ml, using the WHO International Standard $[8,29,30]$. High antibody titers has been reported as above $250 \mathrm{BAU} / \mathrm{ml}[31]$. Recent studies show correlations among antibody titers one month post-vaccination with the occurrence of breakthrough infections[32]; a third vaccine shot is the subject of discussion as it may boost immune systems and block new emerging coronavirus variants [33].

The aim of this study is to evaluate the performance of a new rapid quantitative point-of-care commercially available device from BluSense Diagnostics, based on the SARS-CoV-2 trimeric Spike protein, ViroTrack $^{\circledast}$ Sero COVID-19 Total Ab, with two CLIA laboratory-based immunoassays from Diasorin, LIAISON ${ }^{\circledR}$ SARS-COV-2 S1/S2 IgG and LIAISON ${ }^{\circledR}$ SARS-CoV-2 Trimeric $S$ IgG assay. The performance of the quantitative POC technology was evaluated on capillary- and venous blood drawn from 101 volunteers, employees from Hvidovre Hospital, Denmark. 


\section{MATERIALS AND METHODS}

\section{Subjects and samples}

One hundred and one subjects were included during a three-day study in June 2021 (Characteristics of the study subjects are shown in Table 1). All participants were staff at the Hvidovre Hospital, Denmark, and included individuals from most types of professions (E.g. Doctors, Nurses, Physiotherapists, Cleaning Staff etc). Each study subject was asked to fill in a questionnaire in RedCap on demographics and vaccination status, previous infection with SARS-CoV-2 etc (Table 1). The study was approved by the Regional Ethics Committee of the Capital Region of Denmark (record no. H-20046624 ). The study was further approved by the Regional Data Protection Center (record no. P-2020-358).

\section{Sample collection}

Capillary- and venous blood sample were collected from each of the study subjects. Venous blood, capillary blood and plasma samples (diluted or undiluted) were analysed with the ViroTrack Sero COVID-19 Total Ab. The plasma samples were furthermore analysed on a Diasorin LIAISON ${ }^{\circledast}$ XL Analyzer at the Department of Clinical Microbiology, Hvidovre Hospital. Approximately $5 \mathrm{ml}$ of venous blood was collected per subject in a blood collection tube (BD Vacutainer, UK) treated with potassium ethylenediaminetetraacetic acid (EDTA). Blood was processed following manufacturer's instruction and used for plasma separation. Briefly, blood was centrifuged 15 minutes at $1500 \times \mathrm{g}$ and $20^{\circ} \mathrm{C}$ to obtain plasma.

For analysing capillary blood $20 \mu \mathrm{L}$ was collected with a micropipette or a capillary pipette.

Capillary blood was loaded immediately onto the ViroTrack Sero COVID-19 Total Ab cartridge after collection. Venous blood was stored at room temperature after collection and to a maximal of 5 hours before testing on the ViroTrack Sero COVID-19 Total Ab cartridge and the plasma separation. Plasma was further stored at room temperature and to a maximal of 5 hours before testing onto the ViroTrack Sero COVID-19 Total Ab cartridge. All plasma samples were stored at $-80{ }^{\circ}$ Celsius prior to Diasorin LIAISON ${ }^{\circledR} \mathrm{XL}$ 
medRxiv preprint doi: https://doi.org/10.1101/2021.09.17.21263729; this version posted September 22, 2021. The copyright holder for this

preprint (which was not certified by peer review) is the author/funder, who has granted medRxiv a license to display the preprint in perpetuity.

It is made available under a CC-BY-NC-ND 4.0 International license .

Analyzer testing. For additional investigation and when necessary plasma was diluted in PBS at different dilution factors $(1: 10 ; 1: 20 ; 1: 40)$ and loaded onto the ViroTrack Sero COVID-19 Total Ab cartridge.

\section{ViroTrack Sero COVID-19 Total Ab}

The ViroTrack Sero COVID-19 Total Ab is a POC rapid test providing quantitative results within seven minutes in the range $10-200 \mathrm{BAU} / \mathrm{mL}$ from $20 \mathrm{uL}$ blood, plasma or serum. The test format is composed by a cartridge (ViroTrack Sero COVID-19 Total Ab) and a reader (BluBox).

The platform utilizes a centrifugal microfluidic platform together with an optomagnetic readout based on the agglutination of magnetic nanoparticles (IMA). In brief, $20 \mu$ l of sample is loaded on to the microfluidic cartridge which is then inserted inside the reader (BluBox). In the case of whole blood, the red blood cells are separated from the plasma by centrifugal force. The separated plasma is subsequently resuspended in the pre-stored reagents on the cartridge (e.g. magnetic particles). The magnetic particles are functionalized with SARS-CoV-2 trimeric spike protein and agglutinates in a sample containing anti-spike antibodies. Incubating the particles in a homogeneous magnetic field speeds up the reaction kinetics of the agglutination [34,35]. For optomagnetic detection, a uniaxial alternating magnetic field is applied which periodically aligns the agglutinated particle chains that results in a modulation of the transmitted light proportional with the target concentration [36]. IMA does not require labelled secondary antibodies [37].

The ViroTrack Sero COVID-19 Total Ab is calibrated to the to the "First WHO International Standard for antiSARS-CoV-2 immunoglobulin (code: 20/136)" and the results converted in binding antibody units per milliliter (BAU/ml) by the software up to $200 \mathrm{BAU} / \mathrm{mL}$. Plasma samples with $>200 \mathrm{BAU} / \mathrm{mL}$ where diluted 10 times in PBS and re-measured. Dilution (20 times and 40 times) were continued until a result below 200 $\mathrm{BAU} / \mathrm{mL}$ were obtained. The final binding antibody units per $\mathrm{ml}$ were found by multiplying the dilution factor with the obtained result. During the study four different BlueBox readers were used in parallel. Sample were loaded in different readers in randomized order. 


\section{Diasorin}

The plasma samples were analysed by chemiluminescence immunoassay (CLIA) for SARS-CoV-2 antibodies (IgM and $\lg G$ ) targeting the subunits of the Spike proteins $S 1$ and $S 2$, the trimeric Spike complex or the receptor binding domain (S1-RBD). Samples were analysed on the DiaSorin LIAISON ${ }^{\circledR}$ XL Analyzer using LIAISON ${ }^{\circledR}$ SARS-COV-2 IgM, LIAISON ${ }^{\circledR}$ SARS-CoV-2 S1/S2 IgG and LIAISON ${ }^{\circledR}$ SARS-CoV-2 TrimericS IgG assays. In accordance with a recent study on the specific assay, a negative SARS-CoV-2 result was defined as IgM index $<1.1$ and $\operatorname{lgG}<15 \mathrm{AU} / \mathrm{mL}$, and a positive result was defined as an index value $\geq 1.1 \mathrm{AU} / \mathrm{mL}$ for $\operatorname{lgM}$ and $\geq 15 \mathrm{AU} / \mathrm{ml}$ for $\lg \mathrm{G}$, respectively. A TrimericS $\mathrm{lg} \mathrm{G}$ result was defined as negative $<13 \mathrm{AU} / \mathrm{ml}$, and a positive result defined as values $\geq 13 \mathrm{AU} / \mathrm{ml}$ (equivalent to $\geq 33.8 \mathrm{BAU} / \mathrm{ml}$ ). The LIAISON $^{\circledR}$ SARS-CoV-2 TrimericS IgG assay measures between 4.81 and $2080 \mathrm{BAU} / \mathrm{mL}$. A recent study demonstrated that the DiaSorin SARS-CoV-2 S1/S2 IgG antibodies had a sensitivity of $96.2 \%$ and specificity of $98.9 \%$ [38] . Whereas, the DiaSorin TrimericS IgG has been shown to have a higher sensitivity of $99.4 \%$ and specificity of $99.8 \%$ [22].

Statistical analysis

Spearman rank correlation was measured to evaluate the agreement between the different assays and the different specimen types. Analysis and graphs were performed using PYTHON /R .

\section{RESULTS:}

\section{Participant characteristics}

A total of 101 participants were included. All characteristics can be found in the Table 1. Forty-seven-pointfive percent of participants were between $20-39$ years-old, $44.65 \%$ between $40-59$ years-old and $8 \%$ were 
medRxiv preprint doi: https://doi.org/10.1101/2021.09.17.21263729; this version posted September 22, 2021. The copyright holder for this preprint (which was not certified by peer review) is the author/funder, who has granted medRxiv a license to display the preprint in perpetuity.

It is made available under a CC-BY-NC-ND 4.0 International license .

over 60 years of age. Of 101 participants, 93 were fully vaccinated (received two doses) and one had received only the first dose. Out of the fully vaccinated people, 52 participants received their second dose between two and up to five weeks after the first dose, and 41 participants five weeks (and up to 12 weeks) after the first dose. All the participants who received Astra Zeneca as the first dose, received BNT162b2 mRNA (Pfizer-BioNTech) as their second dose after at least 10 weeks. At the time of the study, all the participants who received BNT162 b2 mRNA had received their second dose between 13 weeks to 29 weeks before the study and all the participants who received ChAdOx1 nCoV-19 (Astra Zeneca) had received their second dose between three to seven weeks before the study.

One capillary blood sample was not collected for one participant.

Table 1 Characteristics of the study subjects

\begin{tabular}{|c|c|c|}
\hline Characteristics & & $\begin{array}{l}\text { Study subjects } \\
\text { (no. 101) }\end{array}$ \\
\hline Age & & $41(23-67)$ \\
\hline \multirow[t]{2}{*}{ Gender } & Female & $89(88 \%)$ \\
\hline & Male & $12(12 \%)$ \\
\hline Body mass index & & $23(19-40)$ \\
\hline Known immunosuppressive disorder & & $3(3 \%)$ \\
\hline Immunosuppressive medication* & & $10(10 \%)$ \\
\hline Smoking & & $3(3 \%)$ \\
\hline \multirow[t]{6}{*}{ Occupation** } & Nurse & $21(21 \%)$ \\
\hline & Junior doctor & $22(22 \%$ \\
\hline & Senior doctor & $5(5 \%)$ \\
\hline & Physiotherapist & $27(27 \%)$ \\
\hline & Secretary & $10(10 \%)$ \\
\hline & Other & $17(17 \%)$ \\
\hline \multirow[t]{3}{*}{ Prior have been infected with SARS-CoV-2 } & One time & $26(26 \%)$ \\
\hline & More than one time & $0(0 \%)$ \\
\hline & Days from infection to test (Median) & 191 (IQR 20-464) \\
\hline Received SARS-CoV-2 vaccination & & $94(93,1 \%)$ \\
\hline $\begin{array}{l}\text { Prior have been infected with SARS-CoV-2 and } \\
\text { vaccinated }\end{array}$ & & $21(21 \%)$ \\
\hline $\begin{array}{l}\text { Have never been infected with SARS-CoV-2 } \\
\text { nor vaccinated }\end{array}$ & & $2(2 \%)$ \\
\hline \multirow[t]{2}{*}{ If vaccinated, first vaccine received ${ }^{* * *}$} & $\begin{array}{l}\text { BNT162b2 mRNA (Pfizer-BioNTech) } \\
\text { (Comirnaty) }\end{array}$ & $87(86 \%)$ \\
\hline & $\begin{array}{l}\text { ChAdOx1 nCoV-19 Astra Zeneca } \\
\text { (AstraZeneca)Vaxzevria) }\end{array}$ & $7(7 \%)$ \\
\hline Days from injection to test (median) $* * * *$ & First injection & 169 (IQR 32- 196) \\
\hline
\end{tabular}


medRxiv preprint doi: https://doi.org/10.1101/2021.09.17.21263729; this version posted September 22, 2021. The copyright holder for this preprint (which was not certified by peer review) is the author/funder, who has granted medRxiv a license to display the preprint in perpetuity.

It is made available under a CC-BY-NC-ND 4.0 International license .

Second injection**** 136 (IQR 21-155)

All values are median and interquartile range

*Includes systemic and local medicine (e.g. steroid nasal spray or inhalation)

** One study subject identified with two occupations

***None of the study subjects received the vaccine from Johnson and Johnson (Janssen Ad26.COV2.S) or Moderna (Spikevax). All vaccinated participants had received Pfizer-BioNTech (Comirnaty) as their second injection regardless of type of the first.

$* * * *$ The day of test was noted as the last study day resulting in an uncertainty of $0-3$ days.

$* * * * *$ One study subject was yet to have the second injection when participating.

\section{Comparison of assay performances in plasma}

Plasma was analysed with both the POC device and the central lab CLIA-based assays. All vaccinated individuals resulted in positive antibody titers with the ViroTrack system and both of the Diasorin IgG assays. Two participants whom were not vaccinated, but previously infected by COVID-19, were found to be negative by Diasorin TrimericS IgG, but to be low positive (20-50 BAU/mL) with ViroTrack for all specimen types.

Figure 1 shows the correlation between LIAISON ${ }^{\circledR}$ SARS-CoV-2 S1/S2 IgG, LIAISON ${ }^{\circledast}$ SARS-CoV-2 TrimericS IgG assays, LIAISON ${ }^{\circledast}$ SARS-CoV-2 IgM and ViroTrack Sero COVID-19 Total Ab for plasma samples.

A strong correlation between ViroTrack and the Diasorin TrimiricS IgG and Diasorin S1/S2 IgG is observed.

The Spearman rank's correlation coefficient is found to be above 0.86 for the correlation between all three methods (see Table 1), and all the p-values are below $<$. The highest correlation with ViroTrack is obtained by the Diasorin Trimeric S assay. The Diasorin M assay do not display any correlation with the other tested methods.
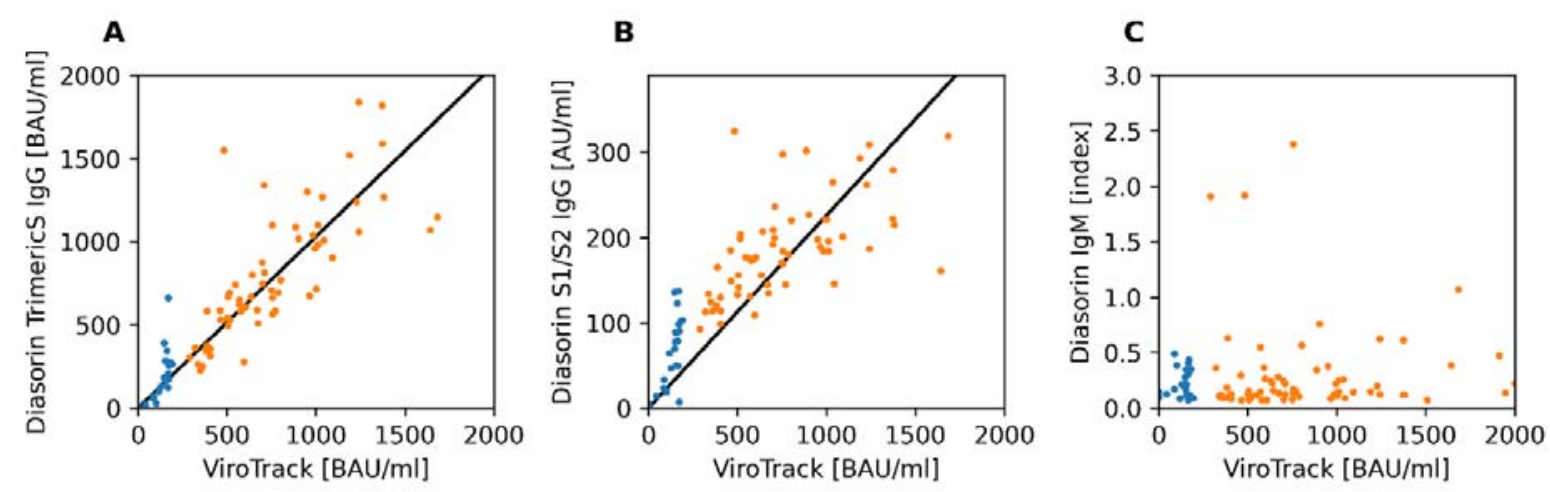

Figure 1: LIAISON ${ }^{\circledR}$ SARS-CoV-2 Trimeric IgG (A), S1/S2 IgG (B) and IgM (C) versus ViroTrack Sero COVID-19 Total Ab. For ViroTrack Sero COVID-19 Total Ab results are shown for diluted plasma (orange points) when $>200 \mathrm{BAU} / \mathrm{mL}$, otherwise undiluted results are shown (blue points). Results inside the dynamic range for Diasorin ( $<2080 \mathrm{BAU} / \mathrm{mL}$ for Trimeric $/ \mathrm{gG}$ and $<400 \mathrm{AU} / \mathrm{mL}$ for $\mathrm{S1} / \mathrm{S2} \mathrm{lg} \mathrm{g}$ ) and below $2000 \mathrm{BAU} / \mathrm{mL}$ obtained for ViroTrack are shown. 
medRxiv preprint doi: https://doi.org/10.1101/2021.09.17.21263729; this version posted September 22, 2021. The copyright holder for this preprint (which was not certified by peer review) is the author/funder, who has granted medRxiv a license to display the preprint in perpetuity.

It is made available under a CC-BY-NC-ND 4.0 International license .

Table 1 Spearman rank's correlation coefficient. 16 samples above the dynamic range for Diasorin ( $2080 \mathrm{BAU} / \mathrm{mL}$ ) are excluded from the analysis.

\begin{tabular}{|c|c|c|c|c|}
\hline & 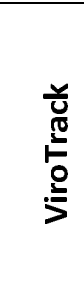 & 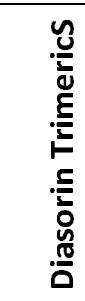 & 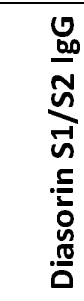 & 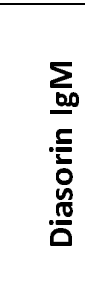 \\
\hline ViroTrack & 1.00 & 0.91 & 0.86 & 0.09 \\
\hline Diasorin TrimericS & - & 1.00 & 0.93 & 0.14 \\
\hline Diasorin S1/S2 IgG & - & - & 1.00 & 0.12 \\
\hline Diasorin $\mathrm{M}$ & - & - & - & 1.00 \\
\hline
\end{tabular}

\section{Comparison among capillary blood, venous blood and plasma results}

Having established the correlation between ViroTrack and the reference test methods, the correlation between different specimen types is investigated. Figure 2 compare the results for different undiluted specimen types for values below $200 \mathrm{BAU} / \mathrm{ml}$. The correlation between capillary blood, venous blood and blood plasma in the dynamic region $(<200 \mathrm{BAU} / \mathrm{ml})$ were high with Spearman rank's correlation coefficients above 0.86 (Figure $2 \mathrm{C}$ ).

A

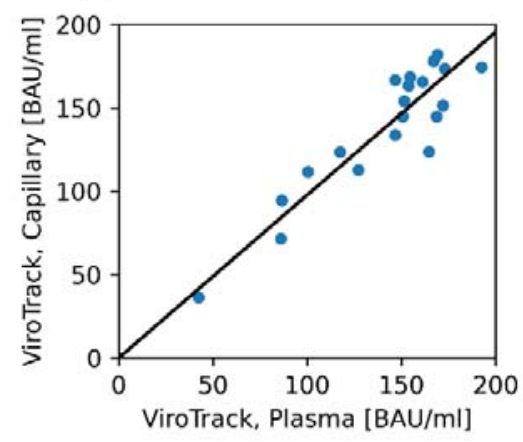

B

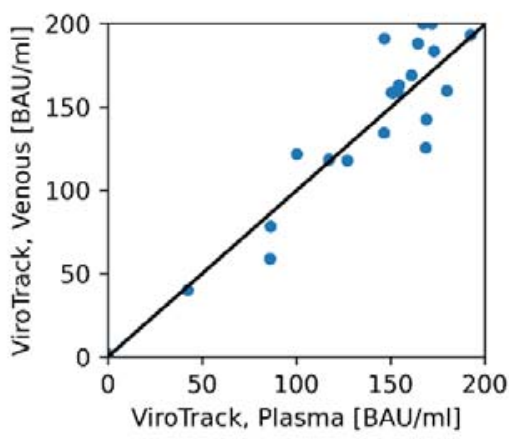

C

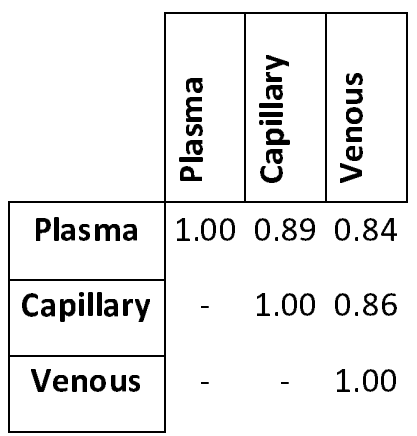

Figure 2 Specimen type agreement between ViroTrack Sero COVID-19 Total Ab results, using capillary, venous blood, and plasma samples. A) undiluted capillary blood versus undiluted plasma samples. B) undiluted venous blood versus undiluted plasma samples. C) Spearman rank's correlation coefficient. Samples above $200 \mathrm{BAU} / \mathrm{mL}$ excluded from the analysis. All p-values are below 
medRxiv preprint doi: https://doi.org/10.1101/2021.09.17.21263729; this version posted September 22, 2021. The copyright holder for this preprint (which was not certified by peer review) is the author/funder, who has granted medRxiv a license to display the preprint in perpetuity.

It is made available under a CC-BY-NC-ND 4.0 International license .

The capability of the assays to correctly quantify a high positive sample (e.g. $>200 \mathrm{BAU} / \mathrm{mL}$ ) can be important as revealed by recent reports correlating between the antibody levels and the immunity against symptomatic COVID-19 infection (Feng et al., 2021a; Khoury et al., 2021). The correlation between the different specimen types measured by ViroTrack and the plasma samples using Diasorin TrimericS IgG for determination of above $200 \mathrm{BAU} / \mathrm{mL}$ is demonstrated in table 3 . The agreements are above $88 \%$ between all specimen types and both methods.

Table 2 Agreement between specimen types and methods for determination of $>200 \mathrm{BAU} / \mathrm{mL}$ in undiluted samples. Values in the square parenthesis are $95 \%$ confidence interval calculated using the Clopper-Pearson method.

\begin{tabular}{|c|c|c|c|c|}
\hline & $\begin{array}{l}\text { ViroTrack, } \\
\text { Plasma }\end{array}$ & $\begin{array}{c}\text { ViroTrack, } \\
\text { Capillary blood }\end{array}$ & $\begin{array}{c}\text { ViroT rack, Venous } \\
\text { blood }\end{array}$ & $\begin{array}{c}\text { Diasorin } \\
\text { TrimericS IgG }\end{array}$ \\
\hline $\begin{array}{r}\text { ViroTrack, } \\
\text { Blood Plasma }\end{array}$ & $\begin{array}{c}100.0 \% \\
{[96.4 \%, 100.0 \%]}\end{array}$ & $\begin{array}{c}95.0 \% \\
{[88.7 \%, 98.4 \%]}\end{array}$ & $97.0 \%[91.5 \%, 99.4 \%]$ & $\begin{array}{c}93.0 \% \\
{[86.1 \%, 97.1 \%]}\end{array}$ \\
\hline $\begin{array}{r}\text { ViroTrack, } \\
\text { Capillary blood } \\
\end{array}$ & $\begin{array}{c}95.0 \% \\
{[88.7 \%, 98.4 \%]} \\
\end{array}$ & $\begin{array}{c}100.0 \% \\
{[96.4 \%, 100.0 \%]}\end{array}$ & $92.0 \%[84.8 \%, 96.5 \%]$ & $\begin{array}{c}88.0 \% \\
{[80.0 \%, 93.6 \%]}\end{array}$ \\
\hline $\begin{array}{r}\text { ViroTrack, } \\
\text { Venous blood }\end{array}$ & $\begin{array}{c}97.0 \% \\
{[91.5 \%, 99.4 \%]}\end{array}$ & $\begin{array}{c}92.0 \% \\
{[84.8 \%, 96.5 \%]}\end{array}$ & $100.0 \%[96.4 \%, 100.0 \%]$ & $\begin{array}{c}90.0 \% \\
{[82.4 \%, 95.1 \%]}\end{array}$ \\
\hline Diasorin TrimericS IgG & $\begin{array}{c}93.0 \% \\
{[86.1 \%, 97.1 \%]}\end{array}$ & $\begin{array}{c}88.0 \% \\
{[80.0 \%, 93.6 \%]}\end{array}$ & $90.0 \%[82.4 \%, 95.1 \%]$ & $\begin{array}{c}100.0 \% \\
{[96.4 \%, 100.0 \%]}\end{array}$ \\
\hline
\end{tabular}

\section{Quantitative results vs vaccination/previous infectious status}

The quantitative results obtained by the POC device has been analysed with respect to the vaccination and previous infected status of the participants. Figure 3 shows a swarm plot of the data. For the previous noninfected who were vaccinated we observe a lower antibody response (median: $569 \mathrm{BAU} / \mathrm{ml}$ ) compared to the infected and vaccinated participants (median: $2000 \mathrm{BAU} / \mathrm{ml}$ ), although for the previously infected we see a large spread of antibody responses (IQR $2651 \mathrm{BAU} / \mathrm{ml}$ compared to $566 \mathrm{BAU} / \mathrm{ml}$ ). In general, we observe a higher antibody response for participants with ChAdOx1 nCoV-19 as the first dose and BNT162b2 mRNA as the second dose (median: $3988 \mathrm{BAU} / \mathrm{ml}$ ) compared to participants receiving both doses with BNT162b2 mRNA (median: 638). However, these participants had all received the second dose with BNT162b2 mRNA less than 50 days before the study, whereas the participants receiving two doses of 
medRxiv preprint doi: https://doi.org/10.1101/2021.09.17.21263729; this version posted September 22, 2021. The copyright holder for this preprint (which was not certified by peer review) is the author/funder, who has granted medRxiv a license to display the preprint in perpetuity.

It is made available under a CC-BY-NC-ND 4.0 International license .

BNT162b2 mRNA in most cases received the second dose more than 125 days before the time of the study.

The time between the injections also varied for the two groups.

Several of the non-infected who received both doses of BNT162b2 mRNA showed values below 200

$\mathrm{BAU} / \mathrm{mL}$. For the previous infected, only participants without any vaccination had values below 200

$\mathrm{BAU} / \mathrm{mL}$.

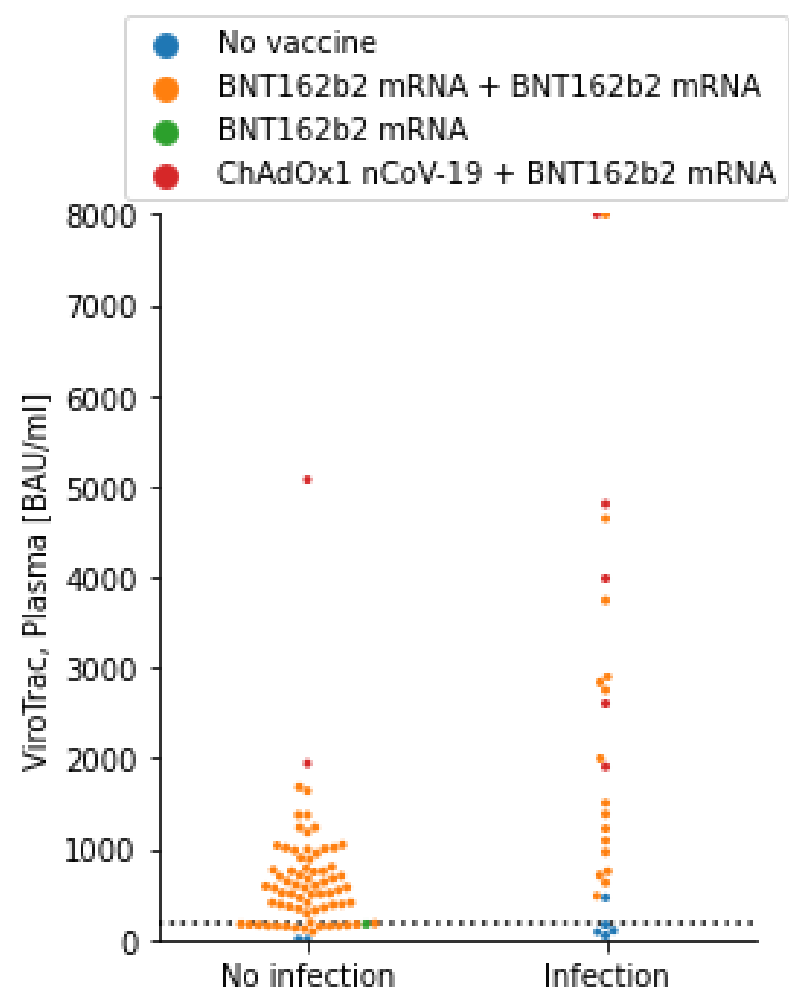

Figure 3 Swam plot of plasma and diluted plasma measured with ViroTrack Sero COVID-19 Total Ab. Data divided into previous PCR confirmed infected (Infection) and previous non-infected (No infection). The dotted line shows $200 \mathrm{BAU} / \mathrm{mL}$.

The study only contained two non-vaccinated and not previous infected participants (see Error! Reference

source not found.). All methods and specimen types gave a negative test result for these two samples.

\section{DISCUSSION:}

To our knowledge, this is the first report comparing the numerical results of a rapid quantitative COVID-19 serology test with a reference CLIA method. Few semi-quantitative rapid serology tests generally based on fluorescence lateral flow tests with a reader exists, but so far only qualitative performances have been 
medRxiv preprint doi: https://doi.org/10.1101/2021.09.17.21263729; this version posted September 22, 2021. The copyright holder for this preprint (which was not certified by peer review) is the author/funder, who has granted medRxiv a license to display the preprint in perpetuity.

It is made available under a CC-BY-NC-ND 4.0 International license .

evaluated [39]. Our study showed a statistically high level of correlation (>0.9) between the results from ViroTrack $^{\circledR}$ Sero COVID-19 Total $A b$ and the two CLIA laboratory-based immunoassays from Diasorin, LIAISON ${ }^{\circledR}$ SARS-COV-2 S1/S2 IgG and LIAISON ${ }^{\circledR}$ SARS-COV-2 Trimeric $S$ IgG assay. The highest correlation, 0.94, was been found with the LIAISON ${ }^{\circledR}$ SARS-COV-2 Trimeric $S \lg G$ assay which utilises the same Spike trimer antigen as ViroTrack ${ }^{\circledR}$ Sero COVID-19 Total $A b$.

Previous reports among various commercial Spike protein based IgG assays (ELISA or CLIA based) showed a lower level of correlation of around 0.7 to 0.8 [26] even when the results are translated in the $\mathrm{BAU} / \mathrm{mL}$ units [25]. The high correlation is obtained even though the POC method measures total antibodies (IgG, $\operatorname{lgM}$ and $\lg \mathrm{A}$ ) while the reference methods measured only $\lg G$ and/or receptor binding domain. The low influence of $\operatorname{IgA}$ and $\operatorname{lgM}$ antibodies may be explained by a low $\operatorname{lgM}$ concentration, a general correlation between $\lg A$ and $\lg G$ titers or the predominance of $\lg G$ antibody class in vaccinated individual.

The agreement among specimen types was satisfactory. As described, the ViroTrack Sero COVID-19 Total $\mathrm{Ab}$ assay is embedded into a centrifugal microfluidics platform where blood is separated into plasma in the initial processing steps. This unique capability allows for the precise quantification without influence of factors as haematocrit, enabling precise correlation with laboratory-based methods. To our knowledge, systematic studies comparing COVID-19 antibodies in different matrixes does not exists, however preliminary studies shows differences in rapid test results when capillary or venous blood is used [40].

We observed a higher antibody response for participants with ChAdOx1 nCoV-19 as the first dose and BNT162b2 mRNA as the second dose less than 50 days prior to the study, compared to the participants who in most cases more than 125 days prior to the study received their second dose of their two doses from BNT162b2 mRNA [41,42].

A limitation of this study is represented by the fact that only two individuals were not infected nor vaccinated; it is therefore not possible to draw any conclusions on the specificity of the POC device vs the reference technique. In a previous study we showed that a first version of the POC test targeting the antibodies against SARS-COV-2 nucleocapsid protein to have higher specificity compared with ELISA based 
medRxiv preprint doi: https://doi.org/10.1101/2021.09.17.21263729; this version posted September 22, 2021. The copyright holder for this preprint (which was not certified by peer review) is the author/funder, who has granted medRxiv a license to display the preprint in perpetuity.

It is made available under a CC-BY-NC-ND 4.0 International license .

methods[37]. Secondly, the study is limited as an extra dilution step was necessary to extend the current dynamic range of the POC device. Which is currently not included in the product "instructions for use" and the dilution process performed in blood may have produced a different result. However, the data demonstrated that the device produce accurate quantification of diluted plasma.

A general agreement $>90 \%$ between capillary blood, venous blood, and plasma from the same samples and techniques has been found thus supporting the use of capillary blood on the POC device for precise decentralized antibodies monitoring post-vaccination and responses after natural infection in countries where the use of vaccines is low or yet to come.

Among the vaccinated only individuals, 17 (18\%) had antibodies below $200 \mathrm{BAU} / \mathrm{ml}$.

Their median time from last vaccination to antibody test was 136 days (IQR; $138.5-130.5)$ compared to 136 days (IQR; $139-130$ ) in those who had above $200 \mathrm{BAU} / \mathrm{ml}$.

The major limitation of our study is the lack of negative controls why we could not determinate specificity and sensitivity. Still, our result show high correlation with a commercial CLIA assay.

None of our assays included antibodies against other isotopes than the spike protein and information on previous infection with SARS-CoV-2 therefore relied on participant memory which could introduce a bias. On the other hand the main purpose of the study was to evaluate the performance of a new technology and our result should not be affected by this.

In conclusion, ViroTrack ${ }^{\otimes}$ Sero COVID-19 Total Ab provides an accurate numerical quantification of the total antibodies against the Spike protein trimer within seven minutes from a single drop of capillary blood. Compared to rapid lateral flow tests detecting antibodies against different forms of the Spike protein the evaluated POC device provides a numerical result in a shorter time.

This capability can enable precise monitoring of antibodies amounts in facilities in various places allowing a potential wider use of quantitative serology tests in the COVID-19 pandemic. 


\section{Conflict of interest ${ }^{1}$ and Funding ${ }^{2}$}

${ }^{1}$ P. Pah, M. Bade, J. Fock, S. and M. Donolato are employed at Blusense Diagnostics APS and have been part of the developing of ViroTrack ${ }^{\circledR}$ Sero COVID-19 Total Ab .

${ }^{2}$ This work was supported by BluSense Diagnostics in forms of providing the test kits for the study.

\section{ACKNOWLEDGEMENTS}

Heike Ebermann from the department of Microbiology, Copenhagen University Hospital, Amager and Hospital, for analyzing the samples on the Diasorin. Laura Catalina Bohorquez for the help in drafting the paper introduction.

1. Krammer F, Simon V. Serology assays to manage COVID-19. Science (80- ). 2020; 368(6495):10601061.

2. Alter G, Seder R. The Power of Antibody-Based Surveillance. N. Engl. J. Med. 2020. p. 1782-1784.

3. Prendecki M, Clarke C, Brown J, et al. Effect of previous SARS-CoV-2 infection on humoral and T-cell responses to single-dose BNT162b2 vaccine. Lancet (London, England). 2021. p. 1178-1181.

4. Walls AC, Park Y-J, Tortorici MA, Wall A, McGuire AT, Veesler D. Structure, Function, and Antigenicity of the SARS-CoV-2 Spike Glycoprotein. Cell. 2020; 181(2):281-292.e6.

5. Barnes $\mathrm{CO}$, Jette $\mathrm{CA}$, Abernathy ME, et al. SARS-CoV-2 neutralizing antibody structures inform therapeutic strategies. Nature. 2020; 588(7839):682-687.

6. Tortorici MA, Veesler D. Structural insights into coronavirus entry. Adv Virus Res. 2019; 105:93-116.

7. Wajnberg A, Amanat F, Firpo A, et al. Robust neutralizing antibodies to SARS-CoV-2 infection persist for months. Science. 2020; 370(6521):1227-1230.

8. Shields AM, Faustini SE, Kristunas CA, et al. Longitudinal protection following natural SARS-CoV-2 infection and early vaccine responses: insights from a cohort of community based dental health care professionals. medRxiv. 2021; :2021.02.24.21252368.

9. Ura T, Yamashita A, Mizuki N, Okuda K, Shimada M. New vaccine production platforms used in developing SARS-CoV-2 vaccine candidates. Vaccine. 2021; 39(2):197-201.

10. Wang F, Kream RM, Stefano GB. An Evidence Based Perspective on mRNA-SARS-CoV-2 Vaccine Development. Med Sci Monit Int Med J Exp Clin Res. 2020; 26:e924700.

11. Jackson LA, Anderson EJ, Rouphael NG, et al. An mRNA Vaccine against SARS-CoV-2 - Preliminary Report. N Engl J Med. 2020; 383(20):1920-1931.

12. Anderson EJ, Rouphael NG, Widge AT, et al. Safety and Immunogenicity of SARS-CoV-2 mRNA-1273 Vaccine in Older Adults. N Engl J Med. 2020; 383(25):2427-2438.

13. Folegatti PM, Ewer KJ, Aley PK, et al. Safety and immunogenicity of the ChAdOx1 nCoV-19 vaccine against SARS-CoV-2: a preliminary report of a phase $1 / 2$, single-blind, randomised controlled trial. Lancet (London, England). 2020; 396(10249):467-478. 
14. Sahin U, Muik A, Derhovanessian E, et al. Concurrent human antibody and T\&lt;sub\&gt;H\&lt;/sub\&gt;1 type T-cell responses elicited by a COVID-19 RNA vaccine. medRxiv. 2020; :2020.07.17.20140533.

15. Sadoff J, Gars M Le, Shukarev G, et al. Safety and immunogenicity of the Ad26.COV2.S COVID-19 vaccine candidate: interim results of a phase $1 / 2 \mathrm{a}$, double-blind, randomized, placebo-controlled trial. medRxiv. 2020; :2020.09.23.20199604.

16. Bal A, Pozzetto B, Trabaud M-A, et al. Evaluation of High-Throughput SARS-CoV-2 Serological Assays in a Longitudinal Cohort of Patients with Mild COVID-19: Clinical Sensitivity, Specificity, and Association with Virus Neutralization Test. Clin Chem. 2021; 67(5):742-752.

17. Bonelli F, Sarasini A, Zierold C, et al. Clinical and Analytical Performance of an Automated Serological Test That Identifies S1/S2-Neutralizing IgG in COVID-19 Patients Semiquantitatively. J Clin Microbiol. 2020; 58(9).

18. Padoan A, Bonfante $F$, Pagliari M, et al. Analytical and clinical performances of five immunoassays for the detection of SARS-CoV-2 antibodies in comparison with neutralization activity.

EBioMedicine. 2020; 62:103101.

19. Patel EU, Bloch EM, Clarke W, et al. Comparative Performance of Five Commercially Available Serologic Assays To Detect Antibodies to SARS-CoV-2 and Identify Individuals with High Neutralizing Titers. J Clin Microbiol. 2021; 59(2).

20. Suhandynata RT, Hoffman MA, Huang D, et al. Commercial Serology Assays Predict Neutralization Activity against SARS-CoV-2. Clin Chem. 2021; 67(2):404-414.

21. Tang MS, Case JB, Franks CE, et al. Association between SARS-CoV-2 Neutralizing Antibodies and Commercial Serological Assays. Clin Chem. 2020; 66(12):1538-1547.

22. Bonelli F, Blocki FA, Bunnell T, et al. Evaluation of the automated LIAISON $\left({ }^{\oplus}\right)$ SARS-CoV-2 TrimericS IgG assay for the detection of circulating antibodies. Clin Chem Lab Med. Germany; 2021; 59(8):1463-1467.

23. Fenwick C, Croxatto A, Coste AT, et al. Changes in SARS-CoV-2 Spike versus Nucleoprotein Antibody Responses Impact the Estimates of Infections in Population- Based Seroprevalence Studies. J Virol. 2021; 95(3):e01829-20.

24. Yanny B, Konyn P, Najarian LM, Mitry A, Saab S. Management Approaches to Hepatitis B Virus Vaccination Nonresponse. Gastroenterol Hepatol (N Y). 2019; 15(2):93-99.

25. Perkmann T, Perkmann-Nagele N, Koller T, et al. Anti-Spike Protein Assays to Determine SARS-CoV-2 Antibody Levels: a Head-to-Head Comparison of Five Quantitative Assays. Microbiol Spectr. 2021; .

26. Šimánek V, Pecen L, Krátká Z, et al. Five commercial immunoassays for sars-cov-2 antibody determination and their comparison and correlation with the virus neutralization test. Diagnostics. 2021; 11(4):1-14.

27. Mahmoud SA, Ganesan S, Naik S, Bissar S, Zamil I, Zaher WA. Evaluation of serological tests for detecting SARS-CoV-2 antibodies: implementation in assessing post vaccination status. medRxiv. 2021; :2021.04.27.21256205.

28. Kristiansen PA, Page M, Bernasconi V, et al. WHO International Standard for anti-SARS-CoV-2 immunoglobulin. Lancet (London, England). 2021. p. 1347-1348.

29. Feng S, Phillips D, White T, et al. Correlates of Protection against symptomatic and asymptomatic 
SARS-CoV-2 infection. medRxiv. 2021; :2021.06.21.21258528.

30. Khoury DS, Cromer D, Reynaldi A, et al. Neutralizing antibody levels are highly predictive of immune protection from symptomatic SARS-CoV-2 infection. Nat Med. United States; 2021; 27(7):12051211.

31. Ruddy JA, Connolly CM, Boyarsky BJ, et al. High antibody response to two-dose SARS-CoV-2 messenger RNA vaccination in patients with rheumatic and musculoskeletal diseases. Ann Rheum Dis. 2021; 0(0):1-2.

32. Bergwerk M, Gonen T, Lustig Y, et al. Covid-19 Breakthrough Infections in Vaccinated Health Care Workers. N Engl J Med. 2021; :1-11.

33. Lawton G. Are booster shots coming? New Sci. 2021; 250(3334):8-9.

34. Mezger A, Fock J, Antunes P, et al. Scalable DNA-Based Magnetic Nanoparticle Agglutination Assay for Bacterial Detection in Patient Samples. ACS Nano [Internet]. 2015; 9(7):7374-7382. Available from: http://pubs.acs.org/doi/abs/10.1021/acsnano.5b02379

35. Antunes $P$, Watterson D, Parmvi M, et al. Quantification of NS1 dengue biomarker in serum via optomagnetic nanocluster detection. Sci Rep [Internet]. Nature Publishing Group; 2015; 5(October):16145. Available from: http://www.nature.com/articles/srep16145

36. Fock J, Hansen MF. Characterization of fine particles using optomagnetic measurements. Int Conf Fine Part Magn. 2016.

37. Moeller ME, Fock J, Pah $\mathrm{P}$, et al. Evaluation of commercially available immuno-magnetic agglutination in comparison to enzyme-linked immunosorbent assays for rapid point-of-care diagnostics of COVID-19. J Med Virol. 2021; 93(5):3084-3091.

38. Ainsworth $\mathrm{M}$, Andersson $\mathrm{M}$, Auckland $\mathrm{K}$, et al. Performance characteristics of five immunoassays for SARS-CoV-2: a head-to-head benchmark comparison. Lancet Infect Dis. 2020; 20(12):1390-1400.

39. FRAGKOU PC, PAPAEVANGELOU V, ANTONIADOU A, et al. Preliminary data of a quantitative point of care test for SARS-CoV-2 antibodies from greece. In Vivo (Brooklyn). 2020; 34(5):3039-3045.

40. Morshed M, Sekirov I, McLennan M, et al. Comparative Analysis of Capillary vs Venous Blood for Serologic Detection of SARS-CoV-2 Antibodies by RPOC Lateral Flow Tests. Open Forum Infect Dis. 2021; 8(3):1-4.

41. Israel A, Shenhar Y, Green I, et al. Large-scale study of antibody titer decay following BNT162b2 mRNA vaccine or SARS-CoV-2 infection. medRxiv [Internet]. 2021; :2021.08.19.21262111. Available from: https://www.medrxiv.org/content/10.1101/2021.08.19.21262111v1\%0Ahttps://www.medrxiv.org/ content/10.1101/2021.08.19.21262111v1.abstract

42. Shrotri M, Navaratnam AMD, Nguyen $V$, et al. Spike-antibody waning after second dose of BNT162b2 or ChAdOx1. Lancet [Internet]. Elsevier Ltd; 2021; 398(10298):385-387. Available from: http://dx.doi.org/10.1016/S0140-6736(21)01642-1 